\title{
Teaching and Learning Innovation among Trainer Lecturer: A Case Study of Undergraduate Students Teaching Training Program at the Polytechnic, Ministry of Higher Education Malaysia
}

\author{
Saifullizam Puteh, Ramah Mada, Azman Hasan \\ Universiti Tun Hussein Onn Malaysia \\ Johor, Malaysia \\ saifull@uthm.edu.my
}

\begin{abstract}
This study aims to identify innovative teaching and learning (PDP), among trainees Degree Technical and Vocational Education (TVE), Universiti Tun Hussien Onn Malaysia (UTHM) for Teaching and Training program. There were four aspects examined in this study to identify the level of technology use, to identify differences in the level of use of technology by program of study, the relationship between technological knowledge and the use of media technologies in PDP, and identify the relationship between institutional supports for the use of media technologies in PDP. The sample consisted of 57 trainee lecturers who underwent training trainee lecturer. This study is a quantitative survey with case study using purposive sample that stated for third semester students SPTV and premiere program. The questionnaire used as an instrument in this study. Data were analyzed using descriptive and inferential statistics using the software Statistical Package for Social Sciences (SPSS) version 21. The results showed that the use of technology is currently on an average interpretation and the value is $(M=3.76, S D=0.72440)$. While the difference analysis using One Way ANOVA showed no significant difference between the level of use of technology by program of study and the significant value is 0.372 . While the correlation analysis using Spearman's Rho correlation of technological knowledge on the use of media technologies in PDP with $(\rho=0.654)$ and a significant value of $p=0.00$. The result shows there is a strong relation and proportional positive between technological knowledge and media technologies. Further, analysis of the relationship between institutional supports for the use of media technology in PDP researcher using Spearman's Rho correlation. Where the $(\rho=-0011)$ and $p=0.934$, indicating that there was no relationship between institutional support for the use of media technology in PDP.
\end{abstract}

Keywords-innovation; learning; teaching

\section{INTRODUCTION}

Teaching and learning using technology is growing like blooms and impact of reforms in the national education system (Benjamin \& Phang, 2012)[1]. Implementation has been made so that all segments of society can experience the technology used in schools and in institutions of higher learning in Malaysia. Therefore, the implementation of innovation in higher education institutions such as polytechnics, community colleges, Vocational College and other institutions in Malaysia gives a new change in pedagogical techniques based on the use of learning technology (Atan \& Andrew, 2010)[2].

The application of technology depends on the effectiveness of the education system and the strong cohesive and knowledge in the use of technology to produce human capital that is creative and innovative trainer lecturers in Malaysia. To realize this statement, the Ministry of Education (MOE) has developed a new transformation of education such as drafting the content of the curriculum, organization, pedagogy and approaches in the classroom that allows the potential for innovation and creativity of the students using technology and so that it can be nurtured more effectively (Shuhada, 2010).

With the changes made to pave the way for students to explore and make discoveries of new learning methods through experiments, projects, inventions and research technology and innovation and learning. As an example of peer discussions, simulations, field trips and activities that allow applications to solve the problem of resources inside and outside the classroom. This implementation also depends on the ability of educators in order to improve and apply the elements of innovation and creativity in teaching practices in and outside the classroom. This is an effort to improve traditional teaching and learning methods (teacher-centered) to more creative approach which is student oriented (studentcentered), for example collaborative, cooperative, projectbased learning, etc. (Sari, 2014)[3].

With help of existing technologies that will be able to foster the development of students during the teaching and learning activities. Where the teachers are able to examine how the students can be active during and after teaching and learning take place with the help of a wide array of technology such as hardware, software and networking software such as Facebook, Twitter, WhatsApp, Telegram and many others. Technological approaches can help teachers assess students in terms of achievement, perception, and cognitive ability. Teachers need to prepare themselves physically, spiritually, emotionally and intellectually high to address any problems that may occur during the implementation of technology in the education system in Malaysia. It is because the students regard the teacher as a facilitator and resource information to them. 
Prospective teachers need to be trained teaching to the real situation in the country's education system. Furthermore, institutions of higher learning produce many high caliber trainers in their respective fields. Therefore Teaching Training program should be emphasized in any educational programs in higher education institutions. Teaching Training Program conducted to provide exposure to the duties of teachers in the classroom and the basic experience of the duties, responsibilities and the role of educators in school (Abu Bakr and Aziz, 2011)[4]. Teaching and training is a key pillar in the training of students to undergo profession as an educator. Moreover, this exercise can help educators implement pedagogy and andragogy in teaching and learning whether through learning strategies, teaching techniques, teaching and learning approaches and so on. It also can help educators in determining the choice of the use of technology in teaching and learning. Thus educators must have the skills and knowledge of existing and new knowledge to improve the level of mastery in applying technology in education. Consequently Chalk Talk as a conventional learning system should be changed to replace the more tech learning patterns. This technology can help educators bridging of the PDP. In addition to learning styles can implement the latest technology, teachers can become agents of change trigger learning by using technology in the new way learning system for students and administrators at the institution. As an example, the use of YouTube in practical learning. While the students are more adept at using technology, but implementation is still less use in the present study. (Yassin, 2012)[5].

In conclusion, innovation in education is the main contributor of human capital development and the economy. The changes can help to generate national income through the education line. When the education system in this country is in a good rank of education world, so that means many foreigners would want to study in Malaysia. Indirectly it can generate state revenues. As we know it, changes in the way teaching and learning in education institutions are changing from time to time. So as educators, we must always be alert to improve the education system from time to time. Furthermore, elements of innovation in education can attract students to generate ideas to the level of critical thinking, creative, innovative and highly skilled and in line with the National Education Philosophy. In addition, the teaching and learning with the help of technology can improve the education system of the conventional learning towards technology-based learning. Teachers also play an important role in realizing the dream state is reached in the education system to implement more technology and innovation in teaching and learning today. A strong effort of physical and mental trainees can give graduates of the institutions that are competitive not only in terms of intellectual development but also proficient in the use of technology (Yeni, 2013)[6].

\section{METHODOLOGY}

In this research, researcher analyzed using descriptive and inferential statistics and case study as a design. The instruments used a questionnaire and a five-point Likert scale. The study involved 57 students, third semester Master FPTV who had undergone training programs teach as respondents. In addition, the selection of the sample in this study is by using purposive sampling. Before the exact research, a pilot study conducted on 10 students from the Faculty of Universiti Teknologi Malaysia (UTM) with the Cronbach alpha coefficient of 0.94 . It is divided into four parts, the first construction is technology (Skill Level), construct the second phase of the use of technology in PDP (Level of Use), third construct technological knowledge and skill level of media technology in PDP, construct four stages of institutional relations in support of PDP. Data obtained from the questionnaire results were analyzed using SPSS version 21. This software is for generating findings from data so that it can analyzed as a percentage of mean, standard deviation, reliability (normality), the difference (One Way ANOVA) and correlation (Spearman's Rho) found in this study.

\section{A. Population and sample}

Selection of the sample population and samples fulfills the objective needs in this study. The population is among the students of Master FPTV 57 students while the sample in this study was 57 students of Master FPTV semester three too.

\section{B. Instrument}

The instrument uses a questionnaire. Part $\mathrm{A}$ is a demographic study, there are three questions. Part B is divided into two parts, Level of Technology and Technology Proficiency Level in the PDP of 34 questions. Part C is of Science and Technology of 19 questions and Part D of Institutional Support to the level of use of technology in the PDP of 19 questions. Refer to Table 1.

\section{Data analysis}

This study was conducted by descriptive and inferential. Table 2 shows the method of data analysis conducted in this study.

TABLE 1. Questionnaire

\begin{tabular}{|l|l|l|l|}
\hline Bil. & \multicolumn{1}{|c|}{ Domain } & \multicolumn{1}{|c|}{ Cronbach Alpha } & \multicolumn{1}{|c|}{$\begin{array}{c}\text { Number of } \\
\text { items }\end{array}$} \\
\hline 1 & Level of technology in PdP (Skill Level) & 0.897 & 34 \\
\hline 2 & $\begin{array}{l}\text { Level of technology in PdP (Level of use technology) } \\
\text { Levels of Knowledge and Skills Technology Media Technology in } \\
\text { Teaching and Learning }\end{array}$ & 0.968 & 19 \\
\hline 3 & $\begin{array}{l}\text { Institutional Support Relations in Teaching and Learning (Institutional } \\
\text { Support) }\end{array}$ & 0.961 & 19 \\
\hline 4
\end{tabular}


TABLE 2: Data Analysis Method

\begin{tabular}{|c|c|c|c|}
\hline OBJECTIVES & ISSUES & APPROACH & ANALYSIS \\
\hline $\begin{array}{l}\text { 1. Identify the level of technology } \\
\text { use among students during their } \\
\text { Masters in Teaching Practice } \\
\text { FPTV. }\end{array}$ & $\begin{array}{l}\text { 1. What is the level of } \\
\text { technology use among } \\
\text { students during their } \\
\text { Masters in Teaching } \\
\text { Practice FPTV? }\end{array}$ & $\begin{array}{l}\text { Quantitative } \\
\text { - Questionnaire }\end{array}$ & $\begin{array}{ll}\text { Descriptive analysis } \\
\text { - } & \text { Min } \\
\text { - } & \text { Percentage }\end{array}$ \\
\hline $\begin{array}{l}\text { 2. Identify the different levels of } \\
\text { technology use among } \\
\text { undergraduate students based on } \\
\text { their course. }\end{array}$ & $\begin{array}{l}\text { 2. Are the differences in the } \\
\text { level of technology use } \\
\text { among undergraduate } \\
\text { students by program of } \\
\text { study? }\end{array}$ & $\begin{array}{l}\text { Quantitative } \\
\text { - Questionnaire }\end{array}$ & $\begin{array}{l}\text { Inferential analysis } \\
-\quad \text { One-way ANOVA }\end{array}$ \\
\hline $\begin{array}{l}\text { 3. Identify the relationship between } \\
\text { technological knowledge and } \\
\text { skills of media technology in } \\
\text { teaching and learning }\end{array}$ & $\begin{array}{l}\text { 3. What is the connection } \\
\text { between technological } \\
\text { knowledge with media } \\
\text { technology skills in teaching } \\
\text { and learning? }\end{array}$ & $\begin{array}{l}\text { Quantitative } \\
\text { - Questionnaire }\end{array}$ & $\begin{array}{l}\text { Inferential analysis } \\
-\quad \text { Spearman's Rho }\end{array}$ \\
\hline $\begin{array}{l}\text { 4. Identify the relationship between } \\
\text { institutional supports for the use } \\
\text { of media technology in PDP. }\end{array}$ & $\begin{array}{l}\text { 4. Does correlation between } \\
\text { institutional supports for the } \\
\text { use of media technology in } \\
\text { the PDP? }\end{array}$ & $\begin{array}{l}\text { Quantitative } \\
\text { - Questionnaire }\end{array}$ & $\begin{array}{l}\text { Inferential analysis } \\
-\quad \text { Spearman's Rho }\end{array}$ \\
\hline
\end{tabular}

\section{RESULTS}

The findings in Part A, Demographic breakdowns are three of gender, program of study and teaching experience. Table 3 shows the frequency distribution by sex, where she spearheaded by as much as $77.2 \%$ and $22.8 \%$ male.

TABLE 3: Frequency Distribution by Gender

\begin{tabular}{|l|l|l|}
\hline Gender & Frequency & $\begin{array}{c}\text { Percentage } \\
(\mathbf{\%})\end{array}$ \\
\hline Male & 13 & 22.8 \\
\hline Female & 44 & 77.2 \\
\hline Total & $\mathbf{5 7}$ & $\mathbf{1 0 0}$ \\
\hline
\end{tabular}

Table 4 shows the frequency distribution by program of study respondents. Where such findings are from Electrical and Electronic Engineering by $33.6 \%$, followed by respondents in Computer Science at 22.8\%, other areas $19.3 \%$, $10.5 \%$ Mechanical Engineering, Technology Management at $7.0 \%$ and the last one is civil engineering by $1.8 \%$.

TABLE 4: Frequency Distribution Based on Prior Learning Program

\begin{tabular}{|l|l|l|}
\hline Programs of study & Amount & Percentage (\%) \\
\hline $\begin{array}{l}\text { Electrical and Electronic } \\
\text { Engineering }\end{array}$ & 22 & 38.6 \\
\hline Mechanical engineering & 6 & 10.5 \\
\hline $\begin{array}{l}\text { Civil and Environmental } \\
\text { Engineering }\end{array}$ & 1 & 1.8 \\
\hline $\begin{array}{l}\text { Management of } \\
\text { Technology }\end{array}$ & 4 & 7.0 \\
\hline Computer Sciences & 13 & 22.8 \\
\hline Other areas & 11 & 19.3 \\
\hline Total & $\mathbf{5 7}$ & $\mathbf{1 0 0}$ \\
\hline
\end{tabular}

Based on Table 5, the majority of respondents have been to do teaching practices between 0-3 months experience by 48 $(84.2 \%)$ while the number of respondents who had been teaching for 5-6 months were $4(7.0 \%)$ and a total of $1(1.8 \%)$ people respondents who had been teaching for 7-9 months, and a total of $2(3.5 \%)$ students who have a 10 to one year of teaching experience and two $(3.5 \%)$ respondents who do not have teaching experience.

TABLE 5: Frequency Distribution Based on Teaching Experience

\begin{tabular}{|l|c|c|}
\hline \multicolumn{1}{|c|}{ Teaching Experience } & Total & $\begin{array}{c}\text { Percentage } \\
(\boldsymbol{\%})\end{array}$ \\
\hline 0-3 month & 48 & 84.2 \\
\hline 5-6 month & 4 & 7.0 \\
\hline 7-9 month & 1 & 1.8 \\
\hline 10-year & 2 & 3.5 \\
\hline No teaching experience & 2 & 3.5 \\
\hline Total & 57 & 100 \\
\hline
\end{tabular}

Analysis shows about level of use of digital technology among students of Master FPTV researchers with 34 items and 34 items divided into three parts, namely the use of technology, computer software and networking software. The results of data analysis showed this study were analyzed using descriptive analysis. Using five points Likert Scale in this study to show a proper and correct answer.

Table 6 shows the results of the study to answer the first question which is a level of use of technology in the PDP, with average interpretation $(\mathrm{M}=3.6982, \mathrm{SD}=0.83291)$. This is likely to encourage the use of less technology in educational institutions teach students exercises. In addition, the trainee lecturer only can use a certain facility in their department. The LCD projector is used to show the high level of consumption because LCD projector technology is one of the facilities provided by the institutions and all the lecturers can use that facility. While the use of laptops also is one of the technologies that had a high level of technology use $(\mathrm{M}=$ $4.65, \mathrm{SD}=0.846$ ), it is because the institutions also provide this to trainees who needed it. In addition, lecturer trainers also have experience in dealing efficiently with laptops because they have their own laptops. 
TABLE 6: Stage of Equipment Digital Technology

\begin{tabular}{|c|l|c|c|c|}
\hline No Item & \multicolumn{1}{|c|}{ Item } & Min (M) & $\begin{array}{c}\text { Standard Deviation } \\
\text { (SD) }\end{array}$ & Interpretation \\
\hline CB1 & Desktop & 4.28 & 1.114 & High \\
\hline CB2 & Laptop & 4.56 & .846 & High \\
\hline CB3 & Mobile computer (handheld computer) & 3.67 & 1.456 & Average \\
\hline CB4 & iPads & 3.28 & 1.449 & Average \\
\hline CB5 & LCD Projector & 3.98 & 1.026 & High \\
\hline CB6 & Digital Camera & 3.72 & 1.221 & Average \\
\hline CB7 & Interactive whiteboard & 3.51 & 1.241 & Average \\
\hline CB8 & Interactive TV & 3.05 & 1.381 & Average \\
\hline CB9 & Interactive CD & 3.44 & 1.180 & Average \\
\hline CB10 & OHP projector & 3.49 & 1.390 & Average \\
\hline & Overall & 3.6982 & .83291 & Average \\
\hline
\end{tabular}

Table 7: Levels of Use of Computer Software

\begin{tabular}{|c|c|c|c|c|}
\hline No Item & Item & $\operatorname{Min}(\mathbf{M})$ & $\begin{array}{c}\text { Standard Deviation } \\
\text { (SD) }\end{array}$ & Interpretation \\
\hline CB11 & Microsoft Word & 4.70 & .597 & High \\
\hline CB12 & Microsoft Power Point & 4.61 & .750 & High \\
\hline CB13 & Microsoft Excel & 4.16 & .960 & High \\
\hline CB14 & Adobe Photoshop & 3.68 & 1.167 & Average \\
\hline CB15 & Adobe Flash & 3.49 & 1.197 & Average \\
\hline CB16 & Adobe Dreamweaver & 3.04 & 1.349 & Average \\
\hline CB17 & Adobe Reader & 3.88 & 1.297 & High \\
\hline CB18 & Movie Marker & 3.49 & 1.269 & Average \\
\hline CB19 & Pscipe & 2.32 & 1.404 & Poor \\
\hline & Overall & 3.7076 & .77711 & Average \\
\hline
\end{tabular}

Table 7 shows the results of the use of computer software in the process of teaching and learning while doing exercises teach. The findings revealed that the use of computer software among respondents is an average interpretation $(\mathrm{M}=3.6088$, $\mathrm{SD}=0.78542$ ). This shows the use of the software during exercise can help trainees to complete their work needs. As an example of using Microsoft Word or recognized as word processing. This software usage is very high $(\mathrm{M}=4.70, \mathrm{SD}=$ 597). It is because software is often used by respondents and has a high existing knowledge in the use of this software.

Table 8: Level of Use Networking Software

\begin{tabular}{|c|l|c|c|c|}
\hline No Item & \multicolumn{1}{|c|}{ Item } & Min (M) & $\begin{array}{c}\text { Standard Deviation } \\
\text { (SD) }\end{array}$ & Interpretation \\
\hline CB21 & Blog & 3.39 & 1.497 & Average \\
\hline CB22 & Skype & 3.61 & 1.346 & Average \\
\hline CB23 & WeChat & 4.14 & 1.093 & High \\
\hline CB24 & Edmodo & 3.82 & 1.241 & High \\
\hline CB25 & Dropbox & 3.95 & 1.301 & High \\
\hline CB26 & YouTube & 4.53 & .889 & High \\
\hline CB27 & Telegram & 4.51 & .782 & High \\
\hline CB28 & WhatsApp & 4.65 & .790 & High \\
\hline CB29 & Facebook & 4.61 & .750 & High \\
\hline CB30 & Yahoo messenger & 3.93 & 1.147 & High \\
\hline CB31 & Electronic mail (email) & 4.09 & 1.138 & High \\
\hline CB32 & Prezi (Power Point online) & 3.28 & 1.320 & Average \\
\hline CB33 & Mind mister (mind mapping) & 3.33 & 1.341 & Average \\
\hline CB34 & Author (Blackboard institutions) & 3.46 & 1.240 & Average \\
\hline CB35 & Internet (LAN, Wi-Fi) & 4.51 & & High \\
\hline & & 3.9871 & & High \\
\hline
\end{tabular}

Table 8 shows the results of using the network software. The results found that the use of networking software and get high interpretation $(\mathrm{M}=3,987, \mathrm{SD}=0.80311)$. This is because the use of network software currently is more popular and easy to use. In addition, the uses of networking software help the learning process directly and indirectly and help simplify the process of two-way communication between students and educators. As an example, the usage of WhatsApp software that is very user-friendly is used for fast response. 
Table 9: Level of Technology

\begin{tabular}{|c|c|c|c|}
\hline Item & Min (M) & Standard Deviation (SD) & Interpretation \\
\hline Level of Use & 3.7977 & 0.71609 & Average \\
\hline
\end{tabular}

Table 9 shows the extent of the use of technology to combine all three constructs and have one domain which is a level of technology used. The overall mean score for level of technology is by $(\mathrm{M}=3.7977, \mathrm{SD}=0.71609)$ with average interpretation. This shows the level of technology used among lecturers during Teaching Practice run. It is because the use of technology is trend nowadays and value is added in education line.

In addition, the use of technology in education institutions is less implemented during the PDP process executed. We can assume the whole process for teaching and learning proses is a conventional teaching. The trainee lecturer was able to give new impetus in education system based on technology. But technology facility in institutions has given less attention for trainee lecturer. Trainee lecturer just use the facilities only for a specific technology. These constraints should be emphasized that the use of technology in education institutions can be implemented on par with today's modernity.

TABLE 10: Comparison of Phase Use Digital Technology Based Learning Program

\begin{tabular}{|l|c|c|c|c|c|}
\hline & Sum of Squares & $\mathrm{df}$ & Mean Square & $\mathrm{F}$ & Sig. \\
\hline Between Groups & 2.218 & 4 & .554 & 1.088 & .372 \\
In Groups & 26.498 & 52 & .510 & & \\
Total & 28.716 & 56 & & & \\
\hline
\end{tabular}

Table 10 shows the results of different studies use technology based on previous studies program respondents. Test conducted by using One-Way ANOVA. The significance of the data analysis is the level of 0.05 . That value is more than 0.05 so they do not have a significant difference. The significance value is 0.372 .
The results showed no significant difference between the uses of technology by program of study respondents. The background of the respondent does not affect the use of technology. This is because the technology is based on one's ability to master technology, whether hardware, software or networks that can assist in the PDP process.

TABLE 11: Score Min Level Use of Technology

\begin{tabular}{|l|c|c|c|}
\hline Type of Study Program & Frequency & Mean & Standard Deviation \\
\hline Electricity & 22 & 4.0126 & .79097 \\
\hline Mechanical & 6 & 3.8426 & .69192 \\
\hline Management Of Technology & 5 & 3.5030 & .25524 \\
\hline Computer Sciences & 13 & 3.7422 & .61412 \\
\hline Other & 11 & 3.5428 & .78612 \\
\hline Total & 57 & 3.7977 & .71609 \\
\hline
\end{tabular}

Table 11 shows the mean score is based on the use of technology in education program respondents. Electrical and Electronic Engineering courses have the highest mean score $($ mean $=4.0126)$, followed by Computer Science $($ mean $=$ $3.7422)$, other courses of (mean = 3.5428), Mechanical Engineering courses $($ mean $=3.8426)$ and the lowest mean

score in the table is Technology Management (mean = 3.5030). This shows that the respondents of Electrical and Electronic Engineering are the most affected respondents in this case study instead of technology during Teaching Practice.

TABLE 12: Relationship between Knowledge and Skills Technology Media In PDP

\begin{tabular}{|c|l|l|}
\hline Spearman's rho correlation & \multicolumn{1}{|c|}{ Knowledge } \\
\hline \multirow{2}{*}{ Skills } & correlation coefficients & $.654 * *$ \\
& Sig. (2-tailed) & 0.000 \\
N & 57 \\
\hline \multicolumn{2}{|c|}{$*$ Correlation is significant at 0.01 (two-tailed) }
\end{tabular}

Table 12 shows the results of a study relationship between technological knowledge and skills of media technology in PDP using Spearman's Rho correlation analysis. The results found that the value of correlation coefficient of the relationship between technological knowledge and skills is ( $\rho$ $=0.654)$. By Sugiyono (2007)[7] stated that the interpretation of the value of correlation the value of $(\rho=0654)$ showed a correlation Spearman's Rho strong and positive proportional. It shows that the relationship between technological knowledge and skills of media technology are intertwined with each other. Knowledge and skills of existing technologies and new can assist the trainee lecturer with good and proper usage of technology.

Through the planning of teaching and learning RMH (Daily Lesson Plan) train lecturer trainers plan their strategies and what technology can be used in this teaching. Therefore lecturers trained trainers to design, develop teaching strategies to use technology. It can assist the trainee lecturer to avoid being awkward when using the current technology Teaching Practice run. 
Thus, knowledge of technology and technology skills are needed in every trainee lecturer to help and apply the technology in PDP. With the knowledge and skills help to increase the use of technology in PDP technology during Teaching Practice run.

TABLE 13: Relationship between Institutional Support and the Used of Technology Media by PDP

\begin{tabular}{|c|l|l|}
\hline \multicolumn{2}{|c|}{ Spearman's rho correlation } & \multicolumn{1}{|c|}{ use of Technology } \\
\hline & correlation coefficients & -.011 \\
institutional support & Sig. (2-tailed) & .934 \\
& $\mathrm{~N}$ & 57 \\
\hline
\end{tabular}

Table 13 shows the results of a study relationship between institutional support and usage of media technology in teaching and learning. Analysis of the results was performed using Spearman's Rho correlation analysis. Based on the table 13, was found that the correlation coefficient for the relationship with the institutional support with the use of media technologies is $(\rho=-0011)$. According to Sugiyono (2007)[7] suggest the interpretation of the correlation value $(\rho$ $=-0011$ ) showed a very low correlation which is negative proportional. Values shown are significant $(\rho=0.934)$ greater than $\mathrm{p}=0.05$ and there was no correlation between institutional support and the use of media technology in teaching and learning. It is claimed that the use of technology is not affected by institutional support. It is because of the use of technology and skills of a person cannot be inherited but can be applied. Thus, the only institution providing technology services but do not apply the use of technology or give training courses for implementing technology in schools.

\section{RESULTS AND DISCUSSION}

The results showed that the level of use of network software technology showed the highest mean score among the three constructs in the domain of technology utilization. Some examples of the network software are Facebook, Blog, Dropbox, WhatsApp and the most popular; YouTube is used by educators in promoting the technology in teaching and learning in education institutions. In addition, today's students are more inclined to use the technology especially in the use of networking software such as WhatsApp, Facebook and many others. As a result, patterns of learning should be modified to better the learning and innovating technology way. It is helping everyday learning system to be more productive and student-centered. The use of technology in the classroom can train students towards becoming independent in learning and teamwork as well as being able to explore the resources to learn something new.

Self-learning and group can assist the trainee lecturer to guide students to understand the concepts, theories that are elusive with the conventional way of delivering learning. Therefore trainee lecturer must carefully plan the design of technology-based teaching and learning to be more systematic. According to Abidin, Yusof, and Hehsan (2014) [8] in a research state collaboration learning with fellow students in the classroom and outside the classroom is the best way to improve new technology in school. Social relationships between students can be a system of information exchange among themselves, increasing the use of technology. In addition, the design of teaching and learning with technology is able to stimulate cognitive and active involvement of students in the classroom. Furthermore, the use of technology helps trainees improve the creativity and innovation of students. Researchers supported the statement by Razak and Nordin (2013) that the use of technology to stimulate thinking and improve the knowledge, and the use of a technology.

Data was collected by researcher about technology used is around of average level. It may be due to lack of implementation of the use of technology in PDP. But lecturer trainers need to apply the values of innovation in teaching and learning so that it can be improve the application of technology to the maximum level. As an example, educators need to diversify the pattern of teaching as creating small groups to complete the tasks given with the aid of existing technology or a new one. Indirectly, educators can implement the use of technology.

The analysis used in this study is a One Way ANOVA analysis, which is to answer this question of the difference between the uses of technology by previous study. One Way ANOVA analysis was used to compare the mean value of the six groups of samples. It aims to determine whether there were significant differences between the variables in this study or not. From the analysis carried out, it showed that there was no significant difference between the use of technology and previous study's responden. Where $\mathrm{p}=0.372$ greater than the value of 0.05 . So the result does not affect the use of the technology and previous study.

Educators need to dominate existing and new technology to apply the technology and be able to teach students during the training practice executed. As an example, trainee lecturer $\mathrm{A}$ is a student of Electrical Engineering and advanced courses using Microsoft Power Point and trainee lecturer B also of the same course, but less adept at using Microsoft Power Point. This shows there is no difference between the uses of technology to previous study program. This is because of the use of technology does not affect the student's previous study but the frequency of students use of technology in teaching and learning.

The results show the group has the lowest means score is a student of Management Technology. These students may be less adept at handling technology and need for advance support such as having some exposure to handling technology or other method to help this group. According to Hassan et al., (2011)[9] stated the trainee lecturer less interested in using technology in PDP because communication and information technology skills they are very poor. Moreover, Hassan et al., (2011) [9] also state to integrate technology in the PDP must have requires a high degree of readiness to produce a new pattern of PDP with competitive, creative and innovative. 
Furthermore, lecturer trainers need to have skills in handling technology to enhance learning technology system effectively during the PDP process. In addition, the use of technology can increase student focus in the classroom. (Mohamed Yusof, et al, 2012) [10]. The conclusion that can be drawn is that the use of technology based learning program does not have a significant difference. Thus, the previous studies do not play a role in technology innovation nowadays.

To investigate the relationship between the two variables, namely knowledge of technology with media technology skills, researchers use methods of analysis Spearman's Rho. The study found a significant relationship between technological knowledge and skills with the proportion of positive and have a strong correlation as a result. (Sugiyono, 2007) [7]. Where trainees should have higher knowledge about technology so that they can to prepare themself and are able to handle of various types of technology during PDP executed. For item number 12 in this questionnaire states that "pemilihan peralatan teknologi dalam PdP dapat meningkatkan tahap pembelajaran pelajar" and item 12 has the highest mean score in this questionnaire. Therefore, knowledge of technology can help trainee lecturer in the selection of appropriate technology tools used in the classroom. In addition, with the help of the TPACK model, it can help trainee lecturer in the selection of appropriate technology. The merger between technological knowledge with media technology skills is to produce good quality of education and be able to raise student's achievement in the classroom. Students are more active when using a technology in PdP compared with conventional studying that uses a static resources and passive in the movement in the classroom. Additionally, they can help to make your cognitive more active and thinking fast to solve any problems occurring during a class. Many multimedia material are used to help students in the classroom to stimulate students' minds with the usage of animation and graphics so that it can attractive with arrangement of audio and video. As an example, the trainee lecturer had a problem in the process of understanding the concept for their students during practical training. With existing technology, knowledge and daily lesson plans, trainers can choose teaching aids with the suitable learning patterns to solve student's inquiry about a certain subject or concept in their study.

Another example is the usage of multimedia movie as a medium of teaching. Multimedia movie can help students to understand better a certain part in subjects. This is because a video can show the students the concept in detail. This teaching method enables the trainee lecturer to observing the student's cognitive and psychomotor student development at the end of video. Nugroho et al., (2013) [11] suggests the use of multimedia to help students to stimulate and advance the interests and aptitudes to study a particular topic. In addition, the existing technology knowledge can be shared and can be applied to a wider and deeper.

According Yahaya (2013) [12] in his study, he stated that the use of Facebook as a medium of teaching and learning. It aims to create an online discussion using Facebook. It is because the software is easy to handle and quick to get feedback. And Khairi (2012) states that the usage of videos is among the multimedia elements which are the most dynamic and realistic compared to other multimedia elements.

The advantage of using technology in teaching and learning can enhance students' interest in the use of technology and can use the technology for information retrieval process. In addition, the use of technology can help students to selflearning and more student-centered. Students are more independent to search resources in the Internet and find a good article and can gain more knowledge through their findings. Thus, trainee lecturer's main role nowadays is to be a facilitator and is able to develop a good strategy in teaching and planning an effective way of using technology in classrooms. With existing technology, knowledge, trainees are able to design and develop learning plans more easily and regularly. Besides of media technology skills trainee lecturer can choose the medium of teaching accordance with the teaching plans and classroom environment.

In conclusion, with the technological knowledge and skills of media technologies, it can help trainee lecturers in planning teaching and learning in a more systematic and effective way. The results showed a significant relationship between technological knowledge and skills of media. Technology has a strong and positive relationship with each other. Thus, the question of this study failed to reject Ho.

The fourth research question was examined using nonparametric analysis of Spearman's Rho where researchers studied the relationship between institutional supports the use of media technology in PDP. The findings stated that there are no correlation between the two variables, namely institutional support and the use of media technology.

A case study conducted in higher educational institutions of Polytechnic. Where there are trainee lecturer running training lecturers teach in this institution. Researchers observed that there laboratories or classrooms that are still incomplete with technological equipment such as LCD display is lacking, limited computer lab for students, computer software is not updated, and Internet access is very weak and so on. This cause the students to feel bored and less focus with service given from the institutions. The institution must feel responsible of this case because the student can help to achieve an institutional goal. So perhaps institution support can infrastructure the service of technology at schools. It can help to improve and develop a good way of teaching using technology. It is supported by Oh \& Reeves (2014) [13] which stated that all parties united spur the integration of technology in the education system so that education sector of our country will improve.

\section{CONCLUSION}

This research was successfully implemented as planned and designed. Aspects level, the relationship and differences between demographic and variables in this study were identified. The findings of the questionnaire survey analysis also supports the materials and the findings of previous studies that help the study of innovation in teaching and learning 
among trainee lecturer to help improve the use of innovative technology. To increase the level of innovation trainee lecturer during their training program, they should teach all parties to work together and cooperate with each other for the success of this innovation.

It is expected that the findings of this study can give a contribution to questions about the use of innovative technology, media technology skills and technology knowledge to solve problems of integrating technology during the Teacher Training Program. Therefore, through this study, it is hoped to help improve efforts to equip him with the level of readiness and confidence in the use of technology, knowledge and skills of high technology that can be applied during Teaching Practice run. This is not only important in producing a trainee lecturer who excel in academics, but also in science and technology, competent, trustworthy, dedicated to the teaching profession to be involved in the future in line with the National Philosophy.

\section{REFERENCES}

[1] Benjamin, M. A. H., \& Phang, F. A. (2012). Technological Pedagogical and Content Knowledge among Undergraduate Education Degree Students at Universiti Teknologi Malaysia. Procedia - Social and Behavioral Sciences, 56, 432-440. doi:10.1016/j.sbspro.2012.09.673

[2] Atan, N. A., \& Andrew, B. (2010). Penggunaan ICT dalam pengajaran dan pembelajaran: sejauh mana ia meningkatkan kemahiran generik guru pelatih Universiti Teknologi Malaysia. Penggunaan Ict Dalam Pengajaran Dan Pembelajaran: Sejauh Mana Ia Meningkatkan Kemahiran Generik Guru Pelatih Universiti Teknologi Malaysia., 1-7.

[3] Sari, R. N. (2014). Penerapan Model Pembelajaran Kooperatif Tipe Teams Games Tournament (TGT) untuk Meningkatkan Prestasi Belajar IPS Pokok Bahasan Perjuangan Melawan Penjajahan Siswa Kelas V MI Bahrul Ulum GUPPI Kembangan Pule Trenggalek Tahun Ajaran 2013/2014. Retrieved from http://repo.iain-tulungagung.ac.id/29/

[4] Abu Bakar, Z., \& Aziz, N. (2011). Kesediaan mengajar dalam kalangan pelajar tahun akhir pendidikan teknikal dan kejuruteraan fakulti pendidikan di Universiti Teknologi Malaysia, Skudai. Journal of Technical, Vocational \& Engineering Education, 2, 64-78

[5]Yassin, S. Z. (2012). Prestasi Guru Pelatih Pengajian Ijazah Sarjana Muda Pengajaran (PISMP). In Prosiding Seminar Penyelidikan Pendidikan $I P G$. Retrieved from http://ojs.cakna.net/index.php/spp/article/view/231

[6] Yeni, E. M. (2013). Inovasi Pembelajaran Matematika Pada Mata Kuliah Kalkulus Lanjutan Melalui Lesson Study. Jurnal Pendidikan Almuslim, 1(1). Retrieved from http://118.97.150.18/jurnal/index.php/JPA/article/view/28

[7] Sugiyono, P. (n.d.). Dr. 2007. Memahami Penelitian Kualitatif.

[8] Abidin, N. M. F. N. Z., Yusof, F. M., \& Hehsan, N. (2014). Aplikasi Iphone: Antara Teknologi Maklumat dan Komunikasi, Media Sosial dan Sebaran Dakwah. Sains Humanika, 2(1). Retrieved from http://www.sainshumanika.utm.my/index.php/sainshumanika/article/vie w/375

[9] Hassan, J., Rahman, A., \& Rashida, F. (2011). Penggunaan ICT dalam proses pengajaran dan pembelajaran di kalangan pendidik Fakulti Pendidikan Universiti Teknologi Malaysia, Skudai, Johor. Unspecified, $1-9$.

[10] Mohamed, H., Judi, H. M., Noor, S. F. M., \& Yusof, Z. M. (2012). Jurang Digital dan Pendidikan di Luar Bandar: Tahap Literasi Teknologi Maklumat dan Komunikasi Pelajar. Asia-Pacific Journal of Information Technology and Multimedia, 1(2), 1-13.

[11] Nugroho, A. B., \& others. (2013). Pemanfaatan Multimedia Untuk Meningkatkan Prestasi Belajar Dan Keaktifan Siswa Pada Mata Pelajaran Pemrograman Mikrokontroller Kelas Xi Di Smk Negeri 2 Salatiga. Universitas Negeri Semarang.

[12] Yahaya, M. F., Sahrir, M. S., \& Nasir, M. S. (2013). Pembangunan Laman Web EZ-Arabic Sebagai Alternatif Pembelajaran Maya Bahasa Arab bagi Pelajar Sekolah Rendah Malaysia. Sains Humanika, 61(1). Retrieved from http://www.sainshumanika.utm.my/index.php/sainshumanika/article/vie $\mathrm{w} / 163$

[13] Oh, E., \& Reeves, T. C. (2014). Generational differences and the integration of technology in learning, instruction, and performance. In Handbook of research on educational communications and technology (pp. 819-828). Springer. Retrieved from http://link.springer.com/chapter/10.1007/978-1-4614-3185-5_66 